\title{
Left renal vein thrombosis: a rare cause of acute scrotal pain
}

\author{
Gael R Nana, ${ }^{1}$ Melvinder Basra, ${ }^{1}$ David D Maudgil, ${ }^{2}$ Amrith Raj Rao ${ }^{3}$
}

'Department of Urology,

Wexham Park Hospital, Slough, UK

${ }^{2}$ Department of Radiology, Wexham Park Hospital, Slough, UK

${ }^{3}$ Department of Urology, Heatherwood and Wexham Park Hospitals NHS Foundation Trust, Slough, UK

\section{Correspondence to} Mr Amrith Raj Rao, amrithrao@yahoo.com
CrossMark

To cite: Nana GR, Basra M, Maudgil DD, et al. BMJ Case Rep Published online: [please include Day Month Year] doi:10.1136/bcr-2013202237

\section{DESCRIPTION}

A 70-year-old man with a history of chronic liver disease presented with increasing scrotal pain and swelling. There was an associated dull left loin pain.

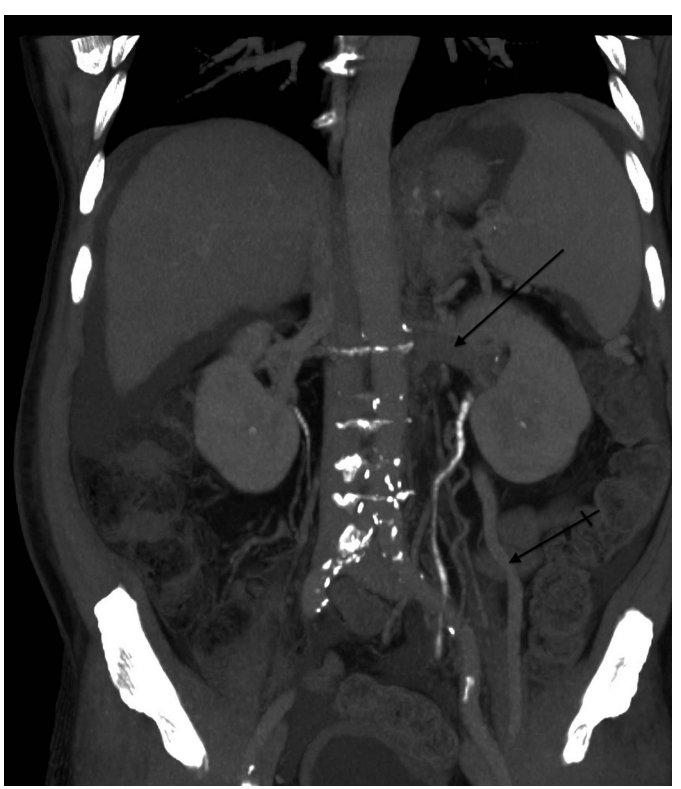

Figure 1 Coronal: abdominal CT scan showing filling defect in the left renal vein (straight arrow) and enlarged left gonadal vein (varicocele, crossed arrow).

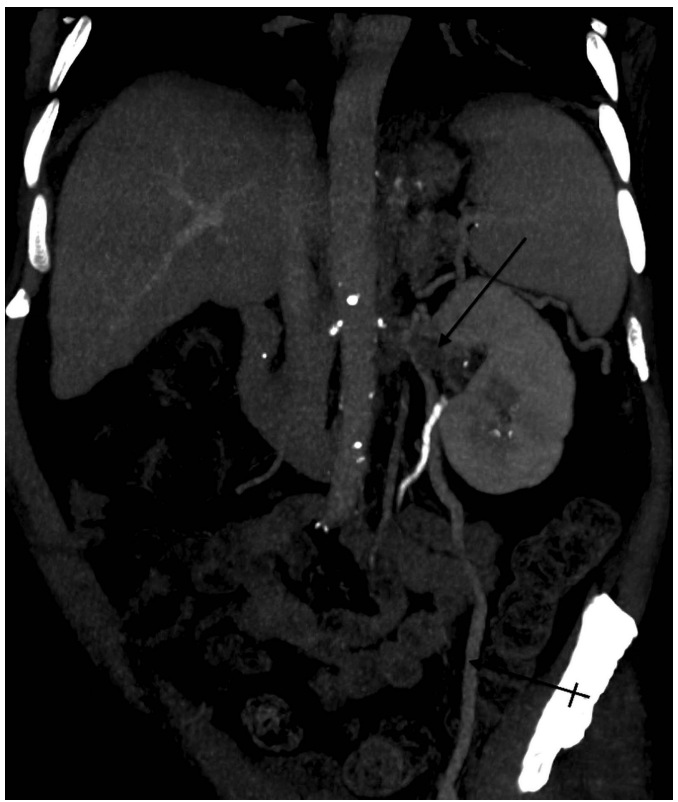

Figure 2 Coronal: coronal reformat of the abdominal CT scan showing filling defect in renal vein (thrombus, straight arrow) and enlarged left testicular vein (varicocoele, crossed arrow).
His general practitioner had started antibiotics after an ultrasound scan revealed hypervascularity of the testes, suggestive of left epididymo-orchitis. An ultrasound scan also revealed a left varicocoele. Blood tests were unremarkable while urinalysis was positive for blood. A CT urogram revealed an oedematous, congested left kidney secondary to an acute left renal vein thrombus with retrograde flow into the left testicular vein, resulting in a left-sided varicocoele (figures 1-3). Following haematology advice, the patient was conservatively managed with anticoagulation, as no definite cause of renal vein thrombosis was detected. The patient remains well with no flank or scrotal pain, with no bleeding diathesis after 6 weeks of low-molecular-weight heparin injections.

Causes of acute varicocoele include renal cell carcinoma and renal vein thrombosis. The commonest cause of renal vein thrombosis in adults is the nephrotic syndrome. Other causes include hypercoagulable states, antiphospholipid syndrome, trauma, etc. No association with chronic liver disease has been

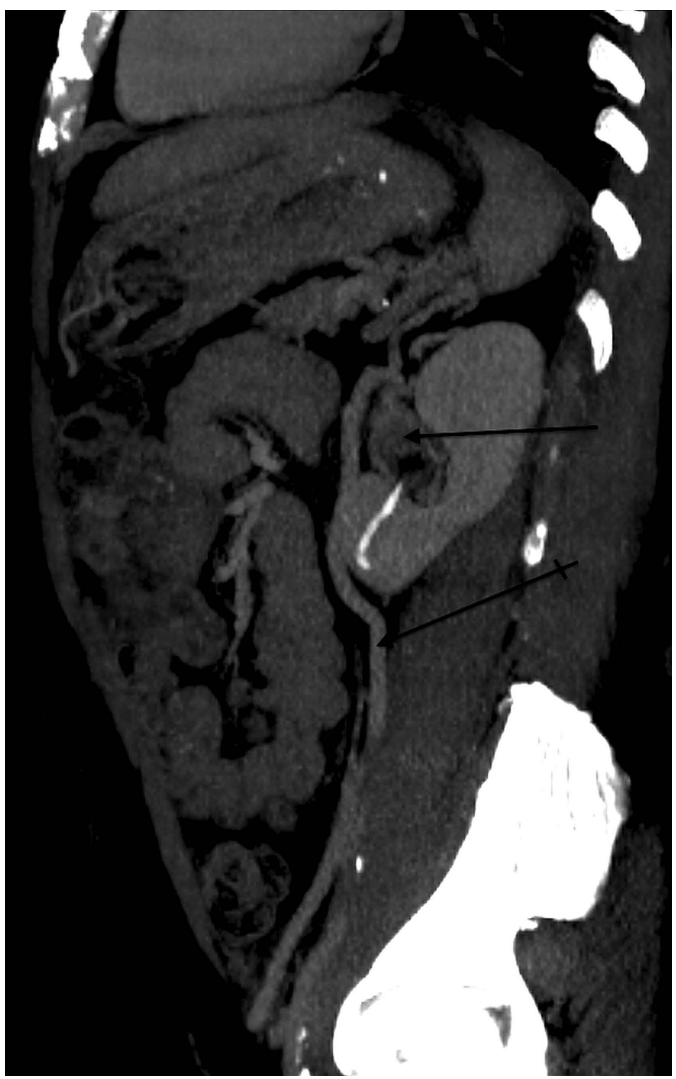

Figure 3 Sagittal: sagittal reformat of the abdominal CT scan showing filling left renal vein thrombus (straight arrow), resulting in engorged left testicular vein (varicocoele, crossed arrow). 
reported. Typically, it presents with loin pain, haematuria and acute kidney injury. Rarely, testicular pain with unilateral varicocoele has been described and our case highlights this unusual presentation. ${ }^{1}$ CT angiography is the gold standard imaging

\section{Learning points}

Left renal vein thrombosis can present with acute scrotal pain and a unilateral varicocoele.

- In any patient with loin pain, acute scrotal swelling and a varicocoele, evaluation of the abdomen and retroperitoneum for underlying malignancy and renal vein thrombosis should be considered.

- Anticoagulation with low-molecular-weight or unfractionated heparin forms the mainstay of the treatment. modality although MR angiography also displays a high diagnostic accuracy. ${ }^{2}$ Anticoagulation prevents clot propagation, while thrombolysis, percutaneous thrombectomy and surgical resection are indicated if there is a risk of renal infarction. ${ }^{3}$

Contributors GRN drafted and wrote the article with critical analysis by MB and ARR. DDM provided the imaging and annotations. All the authors had direct input in the patient's management.

Competing interests None.

Patient consent Obtained.

Provenance and peer review Not commissioned; externally peer reviewed.

\section{REFERENCES}

1 Puthiyaveetil SA, Mathew A. Left renal vein thrombosis causing left-sided varicocele. Intern Med J 2011:41:211-12.

2 Zhang LJ, Wu X, Yang GF, et al. Three-dimensional contrast-enhanced magnetic resonance venography for detection of renal vein thrombosis: comparison with multidetector CT venography. Acta Radiol 2013;54:1125-31.

3 Kim HS, Fine DM, Atta MG. Catheter-directed thrombectomy and thrombolysis for acute renal vein thrombosis. J Vasc Interv Radiol 2006;17:815-22.

Copyright 2014 BMJ Publishing Group. All rights reserved. For permission to reuse any of this content visit http://group.bmj.com/group/rights-licensing/permissions.

BMJ Case Report Fellows may re-use this article for personal use and teaching without any further permission.

Become a Fellow of BMJ Case Reports today and you can:

- Submit as many cases as you like

- Enjoy fast sympathetic peer review and rapid publication of accepted articles

- Access all the published articles

- Re-use any of the published material for personal use and teaching without further permission

For information on Institutional Fellowships contact consortiasales@bmjgroup.com

Visit casereports.bmj.com for more articles like this and to become a Fellow 